\title{
Suppression of Dendritic Cells by HMGB1 Is Associated with Lymph Node Metastasis of Human Colon Cancer
}

\author{
Akiko Kusume $^{\mathrm{a}}$ Tomonori Sasahira ${ }^{\mathrm{a}}$ Yi Luo $^{\mathrm{a}}$ Mamoru Isobe $^{\mathrm{a}}$ \\ Naoya Nakagawa ${ }^{b}$ Naokuni Tatsumoto ${ }^{b}$ Kiyomu Fujii ${ }^{a}$ Hitoshi Ohmori $^{a}$ \\ Hiroki Kuniyasu $^{a}$ \\ a Department of Molecular Pathology, Nara Medical University, Kashihara, ${ }^{b}$ Department of Surgery, Miyoshi Central \\ Hospital, Miyoshi, Japan
}

\section{Key Words}

HMGB1 · Dendritic cells · Apoptosis · Colon cancer

\begin{abstract}
High mobility groupbox-1 (HMGB1) is a multifunctional cytokine secreted by cancer cells, which accelerates cell growth, invasion and angiogenesis in cancer, and induces apoptosis in macrophages. Thioglycolate-stimulated mouse peritoneal macrophages were induced to differentiate into dendritic cells by co-treatment with IL- 4 and GM-CSF. The number of mouse peritoneal macrophage-derived dendritic cells (PMDDCs) showed a dose-dependent decrease in hrHMGB1 treatment. HMGB1-treated PMDDCs showed obvious apoptosis and increased the level of phosphorylated JNK. Intraperitoneal administration of HMGB1 decreased CD205-positive splenic dendritic cells in C57BL mice. To confirm the HMGB1-induced inhibitory effect on dendritic cells, 16 cases of human colon cancer invaded into the subserosal layer were examined. The 8 nodal metastasis-positive cases showed higher nodal HMGB1 concentrations ( $74 \pm 23$ vs. 41 $\pm 15 \mu \mathrm{g} / \mathrm{ml}, \mathrm{p}=0.0116)$ in lymph node tissues and lower CD205-positive nodal dendritic cell numbers ( $86 \pm 22$ vs. $137 \pm 43 / \mathrm{mm}^{2}, p=0.0224$ ) than those in the 8 metastasisnegative cases. Primary tumor tissues of metastasis-positive
\end{abstract}

cases showed higher tumor HMGB1 levels (116 \pm 33 vs. 37 $\pm 18 \mu \mathrm{g} / \mathrm{ml}, \mathrm{p}=0.0007$ ) and lower CD205-positive intratumoral dendritic cell numbers $\left(21 \pm 13\right.$ vs. $62 \pm 23 / \mathrm{mm}^{2}$, $p=0.0068$ ) than those in metastasis-negative cases. These findings suggest that HMGB1 produced by colon cancer cells suppressed nodal dendritic cells to disturb host anti-cancer immunity.

Copyright $\odot 2009$ S. Karger AG, Basel

\section{Introduction}

Dendritic cells play a pivotal role in host immune response to various extrinsic microorganisms and also to cancer cells $[1,2]$. The dendritic cells infiltrating into tumor tissues or in lymph nodes are sentries to the cancer antigens, which are recognized by dendritic cells and presented to T lymphocytes [3]. The presence of dendritic cells is associated with improved survival of colorectal cancer [4]. Dendritic cells are also expected to enhance host responses to cancer vaccination $[5,6]$.

In the present study, we showed that colon cancer escapes from the host anti-cancer immunity by interfering with the antigen-presenting process and decreasing of the number of dendritic cells. Dendritic cell densities in

\section{KARGER}

Fax +4161306 1234 E-Mail karger@karger.ch www.karger.com
(ㄷ) 2009 S. Karger AG, Basel

$1015-2008 / 09 / 0764-0155 \$ 26.00 / 0$

Accessible online at:

www.karger.com/pat
Hiroki Kuniyasu

Department of Molecular Pathology, Nara Medical University

840 Shijo-cho

Kashihara, Nara 634-8521 (Japan)

Tel. +81 74422 3051, Fax +81 74425 7308, E-Mail cooninh@zb4.so-net.ne.jp 
primary and metastatic tumors are reported to be diminished significantly; however, the factors affecting dendritic cell inhibition are still unclear.

Peritoneal macrophage-derived dendritic cells (PMDDCs) are induced from thioglycolate-stimulated murine peritoneal macrophages (PMs), which were induced to dendritic differentiation by treatment with the 2 cytokines (GM-CSF + IL-4), followed by IFN- $\gamma$ + LPS [7]. PMDDCs are reported to express MHC class II molecules at high level and attend to antigen presentation to CD3+ lymphocytes. PMDCCs are useful for examining the dendritic cell response to cytokines [8].

HMGB1 is a dual role protein $[9,10]$, it plays roles in gene transcription [10] and DNA repair as a chromosome structure protein [11] and it is associated with neural development $[12,13]$, cancer progression and inflammation [10] as a secreted cytokine. In the immune system, HMGB1 is pivotal: it acts as a late inflammatory cytokine by activating macrophages in response to LPS [10] and it increases the secretion of inflammatory cytokines (IL$1 \beta$, IFN- $\gamma$, TNF- $\alpha$ ) which worsen septic shock [14]. Furthermore, in various cancers, HMGB1 accelerates disease progression and metastasis by the activation of the specific receptor RAGE [15-20] and a high level of intratumoral HMGB1 induces apoptosis of tumor-associated macrophages, which is associated with lymph node metastasis of colon cancer [21,22].

HMGB1 is released from loose chromatin in necrotic cells and diffuses into the extracellular milieu [23]. The lysates of dying cells induce the maturation of dendritic cells [24]. HMGB1 released from necrotic cells enhances antigen presentation by dendritic cells, leading to $\mathrm{T}$ cell immunity [25]. HMGB1 bound to DNA-containing necrotic substances is recognized by RAGE expressed in dendritic cells [26]. From these findings, we hypothesized that low concentrations of HMGB1 provide activation in monocytes and dendritic cells; however, high concentrations of HMGB1 might provide a death signal to dendritic cells, as found in macrophages. In this study, we attempt to reveal the inhibitory effect of HMGB1 on dendritic cells.

\section{Materials and Methods}

\section{Cell Culture}

Cells were maintained in RPMI-1640 medium (Sigma Chemical Co., St. Louis, Mo., USA) containing 10\% FBS (Sigma) under conditions of $5 \% \mathrm{CO}_{2}$ in air at $37^{\circ} \mathrm{C}$.
Peritoneal Macrophage-Derived Dendritic Cells

Four-week-old male C57BL mice (Japan SLC Inc., Shizuoka, Japan) were injected intraperitoneally with $1 \mathrm{ml}$ of $10 \%$ thioglycolate (Becton-Dickinson Microbiology Systems, Sparks, Md., USA). On the 4th day, the rats were sacrificed and the peritoneal cavities were washed with cold PBS to collect infiltrated macrophages. The lavages were centrifuged, and the pellets were resuspended in 10\% FBS supplemented RPMI-1640 medium. Suspended cells were cultured overnight. Adherent cells (peritoneal macrophages) were reseeded at $1 \times 10^{4}$ cells per well in 24-well dishes. Dendritic cell differentiation was performed according to Makala et al. [7]. The peritoneal macrophages were treated with mouse recombinant interleukin-4 (Peprotec Ltd., London, UK; $1,000 \mathrm{U} / \mathrm{ml}$ ) and mouse recombinant granulocyte-macrophagecolony stimulating factor (Peprotec Ltd.; 1,000 U/ml) for 1 week. Then the cells were treated with mouse recombinant interferon- $\gamma$ (Peprotec Ltd.; $250 \mathrm{U} / \mathrm{ml}$ ) and LPS (Sigma; $250 \mu \mathrm{g} / \mathrm{ml}$ ) for $72 \mathrm{~h}$. Human recombinant HMGB1 was purchased from Abnova Corp. (Taipei City, Taiwan). For neutralization of HMGB1, anti-HMGB1 antibody (New England Biolabs Inc., Beverly, Mass., USA) was used. For cell labeling, PKH26 chemifluorescent dye (Zynaxis Inc., Malvern, Pa., USA) was used according to the provider's instructions [21]. Infiltration of labeled cells was observed at $480 \mathrm{~nm}$ with a fluorescence microscope.

Immunoblot Analysis

Whole-cell lysates were prepared as described previously [27]. Fifty-microgram lysates were subjected to immunoblot analysis in $12.5 \%$ SDS-polyacrylamide gels followed by electrotransfer to nitrocellulose filters. The filters were incubated with primary antibody and then with peroxidase-conjugated IgG antibody (Medical and Biological Laboratories, Nagoya, Japan). A $\gamma$-tubulin antibody was used to assess the levels of protein loaded per lane (Oncogene Research Products, Cambridge, Mass., USA). The immune complex was visualized with an ECL Western-blot detection system (Amersham, Aylesbury, UK). Primary antibodies included anti-HMGB1 antibody (Upstate Biotechnology Inc., Lake Placid, N.Y., USA), and anti-phospho-JNK, anti-caspase 3, anticaspase 9 antibodies (Santa-Cruz Biotechnology, Santa Cruz, Calif., USA), anti-human CD205 (DEC-205) and anti-CD86 antibodies (Dako, Carpinteria, Calif., USA). CD86, a B-7 family ligand of CD28, a major T cell costimulatory receptor, is a marker of mature dendritic cells.

\section{Cell Growth}

Cells were seeded at a density of 10,000 cells per well in 24-well tissue culture plates. MTT (3-(4,5-dimethylthiazol-2-yl)-2,5-diphenyltetrazolium bromide; Sigma) was added to the culture medium at a concentration of $25 \mu \mathrm{g} / \mathrm{ml}$ for $30 \mathrm{~min}$. After removal of the medium, $1 \mathrm{ml}$ DMSO was added to dissolve formazan pigment, and $200 \mu \mathrm{l}$ of the DMSO were examined at $540 \mathrm{~nm}$. The experiments were performed in triplicate.

Assessment of Apoptosis

Apoptosis was assessed by staining with Hoechst33258 fluorescent dye (Wako Pure Chemical Industries Ltd., Osaka, Japan). The number of apoptotic cells was counted by observation of 1,000 cells. 


\section{Animal Model}

C57BL mice were purchased from Japan SLC Inc. (Shizuoka, Japan). The mice were maintained according to institutional guidelines approved by the committee for animal experimentation of Nara Medical University, in accordance with the current regulations and standards of the Ministry of Health, Labour and Welfare. The mice were used according to the institutional guidelines when they were 5 weeks old. Human recombinant HMGB1 (500 $\mu \mathrm{g} / \mathrm{mouse})$ or PBS was administrated into each peritoneal cavity of 4 mice. Two days after the administration, mice were sacrificed and the spleens were taken for immunohistochemistry.

\section{Surgical Specimens}

Formalin-fixed, paraffin-embedded archival surgical specimens from 16 patients with primary colon adenocarcinomas that had invaded the subserosal layer were randomly selected from Miyoshi Central Hospital. Out of 16 cases, 8 were metastasis-negative (Dukes' stage B), and 8 showed nodal metastasis (Dukes' stage C). Because written informed consent was not obtained, identifying information for all samples was removed before analysis for strict privacy protection; the procedure was in accordance with the ethical guidelines for human genome/gene research enacted by the Japanese government.

\section{Immunohistochemistry}

Consecutive $4-\mu \mathrm{m}$ sections were immunohistochemically stained using the immunoperoxidase technique described previously [15]. Anti-ED2 and anti-mouse CD205 (NLDC-145) antibodies (BMA Biomedicals, Augst, Switzerland) and anti-human CD205 (DEC-205) antibody (Dako) were used at a concentration of $0.5 \mu \mathrm{g} / \mathrm{ml}$. CD205 is a mannose receptor-like membrane glycoprotein. CD205 is expressed in almost all types of dendritic cells. Secondary antibodies (Medical and Biological Laboratories) were used at a concentration of $0.2 \mu \mathrm{g} / \mathrm{ml}$. The specimens were color-developed with diamine benzidine hydrochloride (Dako). Meyer's hematoxylin (Sigma Chemical Co.) was used for counterstaining. For counting dendritic cells or macrophages, 20 high power fields containing lymph follicles and 20 high power fields containing paracortical areas and sinus were observed in each lymph node specimen. In tumor tissues, dendritic cells were counted from observation of 20 high power fields.

\section{Enzyme-Linked Immunosorbent Assay (ELISA)}

Cytosol/membrane fraction was used for ELISA assay. Frozen tissues of lymph nodes were minced and suspended with STKM buffer $\left(50 \mathrm{mM}\right.$ Tris $\mathrm{HCl} \mathrm{pH} \mathrm{7.5,} 25 \mathrm{mM} \mathrm{KCl}, 5 \mathrm{mM} \mathrm{MgCl}_{2}, 0.25 \mathrm{M}$ sucrose, $10 \mu \mathrm{g} / \mathrm{ml}$ leupeptin, $50 \mu \mathrm{g} / \mathrm{ml}$ phenylmethylsulfonyl fluoride) and homogenized in Dounce-pestles by 150 strokes. After centrifugation at $1,000 \mathrm{~g}$ for $5 \mathrm{~min}$, the supernatant was used for ELISA [28]. The pellet containing nuclear material was abandoned. HMGB1 concentration was detected by HMGB1 ELISA kit (Shinotest, Tokyo, Japan) according to the provider's instructions.

\section{Statistical Analysis}

Statistical analyses of experimental data were carried out by Mann-Whitney U test and ANOVA test. Statistical significance was defined as a 2 -sided $\mathrm{p}<0.05$.

HMGB1 Suppresses Dendritic Cells
Table 1. Mean HMGB1 concentration and dendritic cell numbers in regional lymph nodes of 16 human colon cancer cases

\begin{tabular}{|c|c|c|c|}
\hline & \multicolumn{2}{|c|}{ Nodal metastasis } & \multirow[t]{2}{*}{$\mathrm{p}$ value } \\
\hline & $\begin{array}{l}\text { positive } \\
(\mathrm{n}=8)\end{array}$ & $\begin{array}{l}\text { negative } \\
(\mathrm{n}=8)\end{array}$ & \\
\hline HMGB1, $\mu \mathrm{g} / \mathrm{g}$ & $71 \pm 23$ & $41 \pm 15$ & 0.0116 \\
\hline Dendritic cells, $\mathrm{n} / \mathrm{mm}^{2}$ & $86 \pm 22$ & $137 \pm 43$ & 0.0224 \\
\hline
\end{tabular}

Table 2. Mean HMGB1 concentration and dendritic cell numbers in primary lesions of 16 human colon cancer cases

\begin{tabular}{lccc}
\hline & \multicolumn{2}{l}{ Nodal metastasis } & p value \\
\cline { 2 - 3 } & $\begin{array}{l}\text { positive } \\
(\mathrm{n}=8)\end{array}$ & $\begin{array}{l}\text { negative } \\
(\mathrm{n}=8)\end{array}$ & \\
\hline $\mathrm{HMGB} 1, \mu \mathrm{g} / \mathrm{g}$ & $116 \pm 33$ & $37 \pm 18$ & 0.0007 \\
Dendritic cells, $\mathrm{n} / \mathrm{mm}^{2}$ & $21 \pm 13$ & $62 \pm 23$ & 0.0068 \\
\hline
\end{tabular}

\section{Results}

\section{Dendritic Differentiation of Mouse Peritoneal \\ Macrophages}

To examine the effect of HMGB1 on dendritic cells, we induced dendritic differentiation of mouse peritoneal macrophages by sequential treatment with IL-4 + GMCSF and IFN- $\gamma+$ LPS. The PMDDCs showed larger size cell with dendritic processes (fig. 1b) in comparison with undifferentiated peritoneal macrophages (fig. la). Dendritic cell differentiation of PMs was confirmed by expression of CD86 and CD205 (fig. 1c). Expression of CD86 and CD206 was detected in PMDDCs but not in PMs.

\section{Effect of HMGB1 on PMDDCs}

HMGB1 treatment showed an inhibitory effect on both PMs and PMDDCs in a dose-dependent manner (fig. 2a). PMDDCs showed less sensitivity to HMGB1 than did PMs. To confirm the inhibitory effect of HMGB1 on PMDDCs, HMGB1 in the culture media was neutralized by specific antibody (fig. 2b-f) and the cells recovered from the HMGB1-induced inhibition.

Next we counted apoptotic cells treated by the HMGB1 in a dose-dependent manner (fig. 1g). HMGB1 increased phosphorylation of JNK and protein levels of caspases 3 and 9 (fig. 1h). Thus, HMGB1 inhibited PMDDCs by induction of JNK-associated apoptosis. 

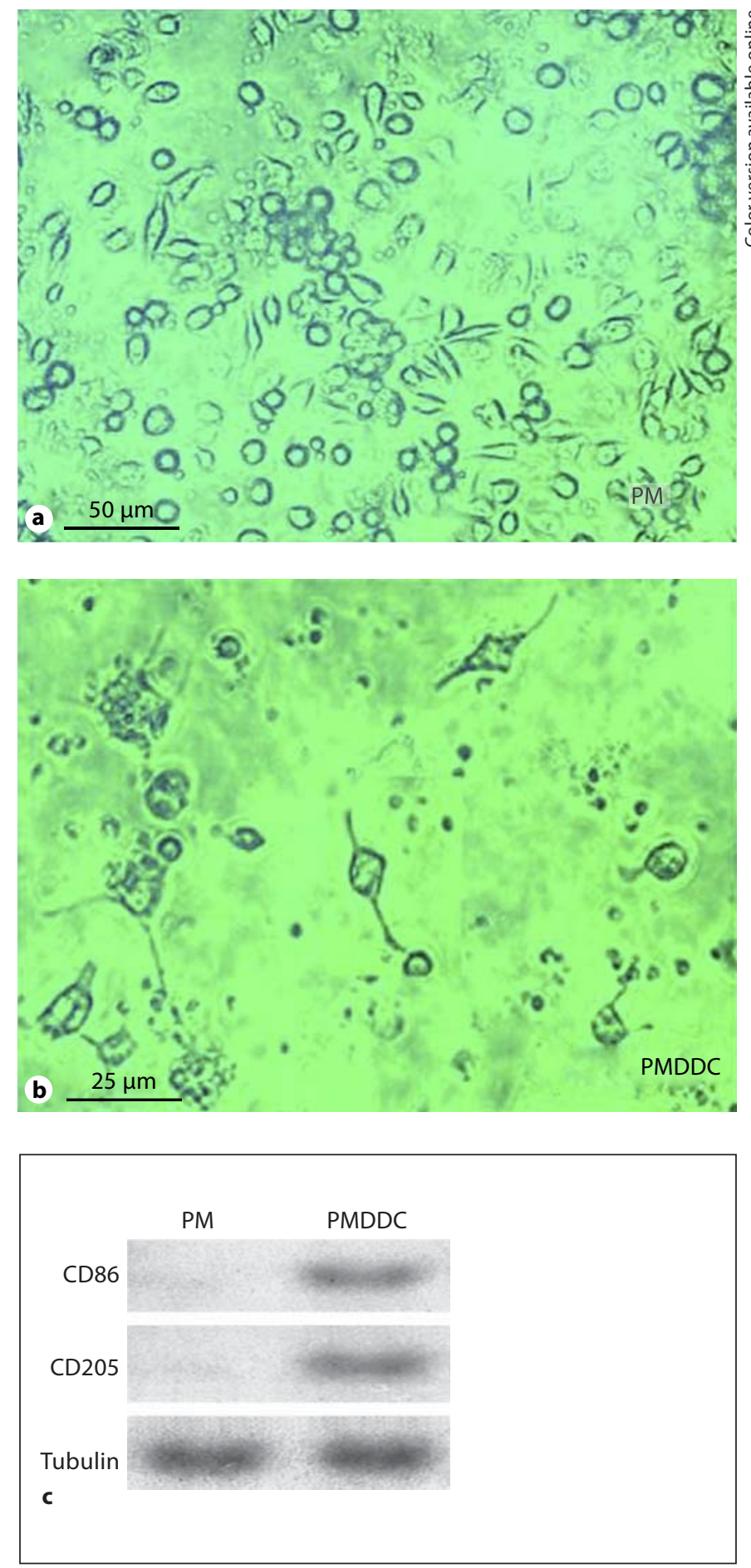

Fig. 1. Induction of dendritic differentiation in mouse peritoneal macrophages. Microscopical appearances of peritoneal macrophages obtained from mouse PM (a) and PMDDC (b). c Expression of CD86 and CD205 in PM and PMDDC. Tubulin served as an internal control.
Effect of HMGB1 on Spleen Dendritic Cells in Mice

We next examined the effect of HMGB1 on dendritic cells in the spleens of mice (fig. 2). After administration of HMGB1 into the peritoneal cavity, the spleens were examined by immunohistochemistry. In HMGB1-treated mice, ED2-positive splenic resident macrophages were reduced to $37 \%$ of those in PBS-treated mice (fig. 2a) and CD205-positive dendritic cells were reduced to 53\% (fig. 2a). Thus, the sensitivity of dendritic cells to HMGB1-induced inhibition is lower than that of macrophages.

\section{HMGB1 Concentration and Dendritic Cells in}

Regional Lymph Nodes of Human Colon Cancer

In vitro and in the animal model, HMGB1 has an inhibitory effect on dendritic cells. To confirm the role of HMGB1 on colon cancer metastasis, the regional lymph nodes of 16 serosa-invading human colon cancers were examined for HMGB1 concentration and the number of dendritic cells by ELISA and immunohistochemistry (table 1, fig. 3). The nodal HMGB1 concentration (74 \pm 23 $\mu \mathrm{g} / \mathrm{ml}$ ) of the 8 nodal metastasis-positive cases was higher than that of the 8 metastasis-negative lymph node cases $(41 \pm 15 \mu \mathrm{g} / \mathrm{ml}, \mathrm{p}=0.0116)$. The number of CD205positive nodal dendritic cells $\left(86 \pm 22 / \mathrm{mm}^{2}\right)$ was lower than that in metastasis-negative cases $\left(137 \pm 43 / \mathrm{mm}^{2}\right.$, $\mathrm{p}=0.0224)$. HMGB1 concentrations in the regional lymph nodes were correlated with those in the primary tumors of the same cases (data not shown). Thus, nodal metastasis-positive cases showed higher nodal HMGB1 levels and lower numbers of nodal dendritic cells than those in metastasis-negative cases.

\section{HMGB1 Concentration and Dendritic Cells in \\ Primary Lesions of Human Colon Cancer}

Finally, we examined the tumor HMGB1 concentration and the number of dendritic cells in primary tumor tissues in the 16 human colon cancer cases (table 2, fig. 3). Tumor tissues of metastasis-positive cases showed higher HMGB1 concentration $(116 \pm 33$ vs. $37 \pm 18 \mu \mathrm{g} / \mathrm{ml}, \mathrm{p}=$

Fig. 2. Effect of HMGB1 on PMDDCs. a Dose-dependent inhibitory effect of HMGB1 on PM and PMDCC. b-f Chemiluminescence-labeled PMDCCs were treated with HMGB1 and anti-HMGB1 antibody. g Apoptosis induction by HMGB1 on PMDDCs. Apoptotic cells were counted by Hoechst dye staining. h HMGB1 induced phosphorylation of JNK and increases of caspase 3 and caspase 9 in PMDCCs. Tubulin served as a loading control. Bars $=$ SD from 3 independent experiments. 


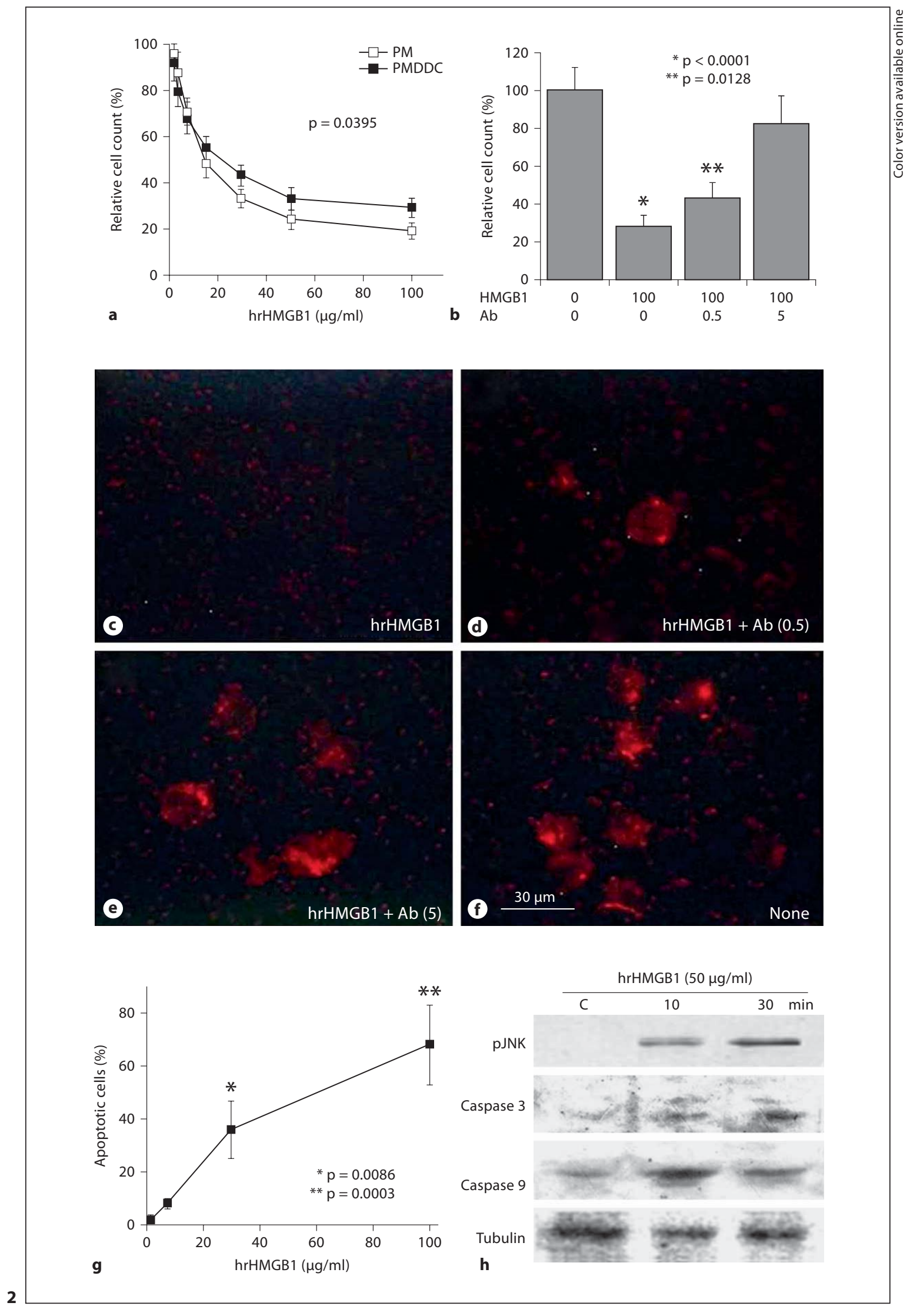




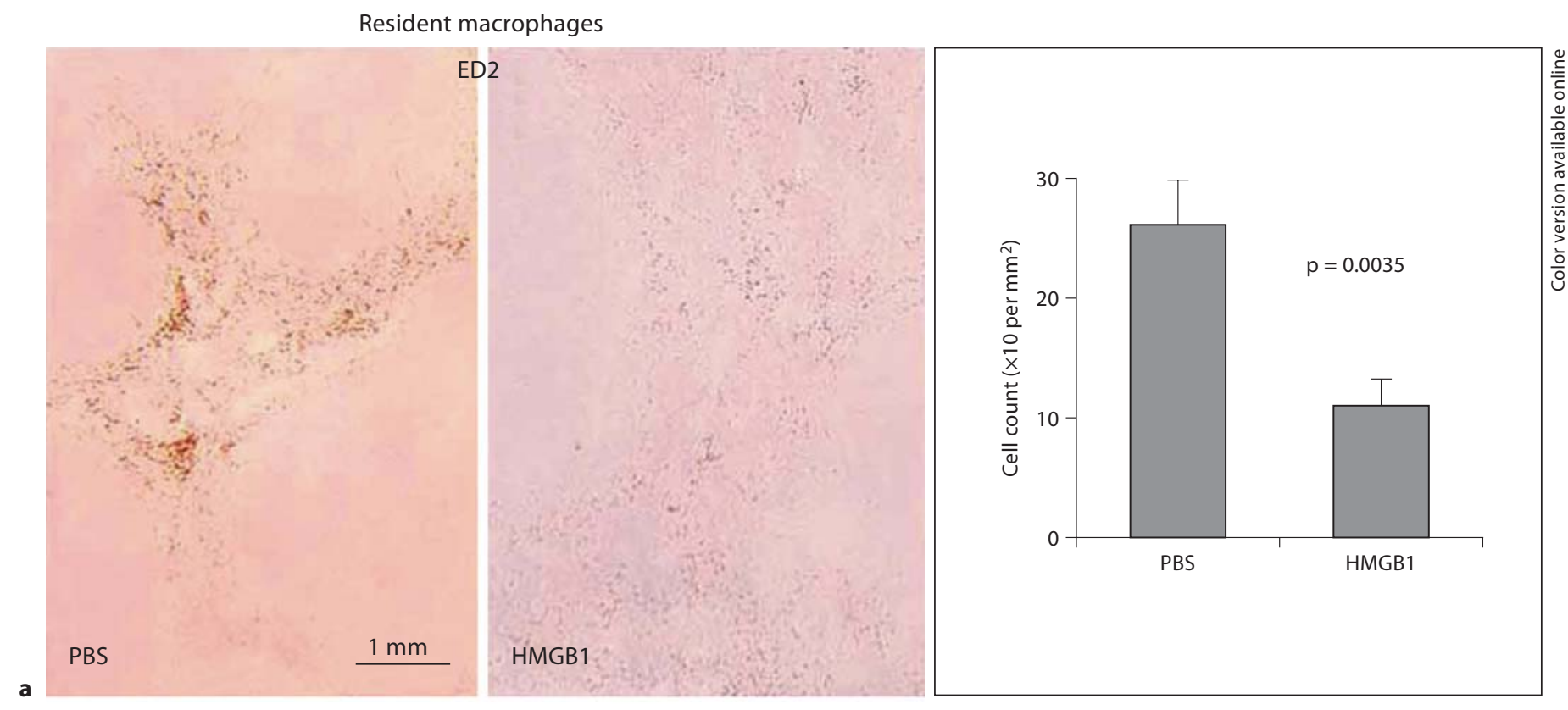

Dendritic cells

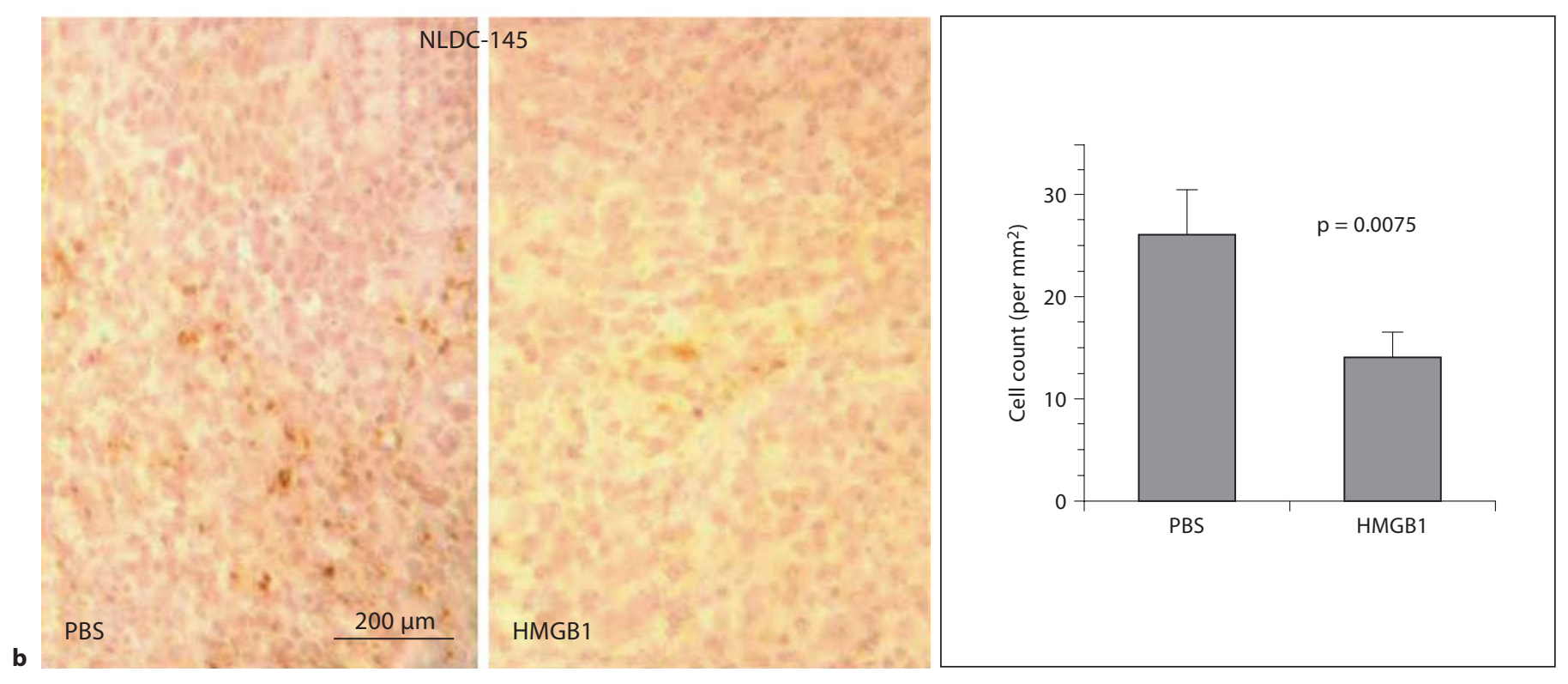

Fig. 3. Effects of HMGB1 on resident macrophages and dendritic cells in mouse spleen. HMGB1 was administrated into the peritoneal cavity of C57BL mouse. ED2-positive resident macrophages (a) and CD205-positive dendritic cells (b) were counted by immunohistochemistry. Bars = SD from 3 independent experiments.

0.0007) and lower CD205-positive dendritic cell numbers $\left(21 \pm 13\right.$ vs. $\left.62 \pm 23 / \mathrm{mm}^{2}, \mathrm{p}=0.0068\right)$ than those in metastasis-negative cases. Thus, nodal metastasis-positive cases showed higher tumor HMGB1 levels and lower numbers of intratumoral dendritic cells than those in metastasis-negative cases.

\section{Discussion}

HMGB1 is secreted from cancer cells and enhances cancer cell invasion and metastasis in colon cancer $[16$, 17]. HMGB1 secretion is increased by IL- 15 and TGF- $\alpha$, which are also secreted from cancer cells [29]. Thus, 
Fig. 4. CD205-positive dendritic cells in regional lymph node and the primary tumor of human colon cancer. CD205-positive dendritic cells were detected by immunohistochemistry in human colon cancer. A Dukes' B and a Dukes' C case were examined. Bar $=100 \mu \mathrm{m}$.

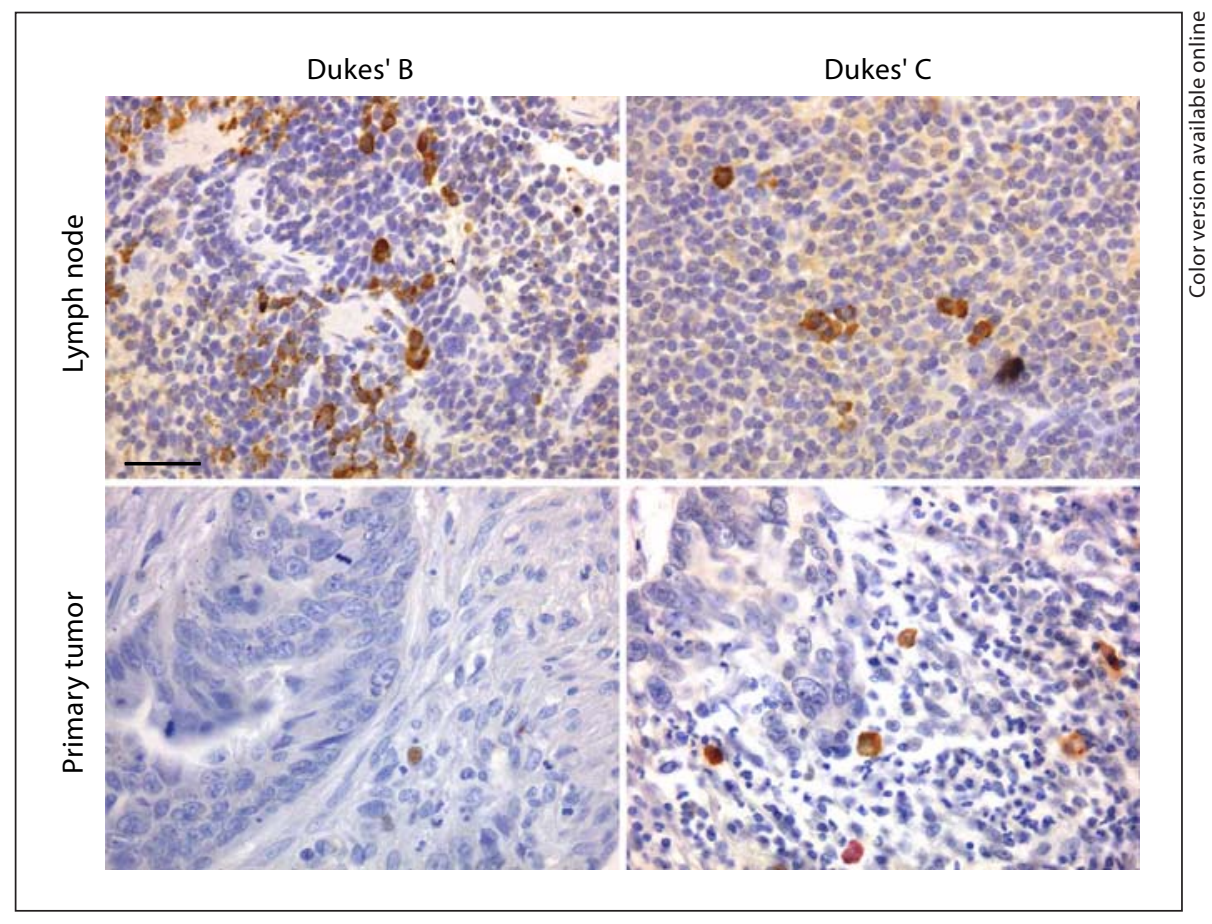

HMGB1 acts as autocrine/paracrine tumor growth factor in colon cancer.

We also reported that HMGB1 possesses a pro-apoptotic effect on macrophages [21]. Colon cancers producing high levels of HMGB1 result in fewer tumor-associated macrophages and higher frequency of nodal metastasis [22]. Thus, HMGB1 produced from colon cancer cells show 2 effects: cancer cell progression and macrophage inhibition, which might accelerate disease progression in colon cancer.

Our next question was whether HMGB1 has some other effects on monocyte-lineage immune cells. In the present study, we revealed that HMGB1 inhibits dendritic cells by inducing apoptosis, which is associated with lymph node metastasis of colon cancer. We have previously shown that HMGB1 provides JNK phosphorylation in PMA-induced macrophage-differentiated U937 cells, which causes apoptosis. In PMDDCs, HMGB1 also provided JNK phosphorylation with increases in caspases 3 and 9 , which are associated with apoptotic signals.

Dendritic cells possess a key role as antigen presenting cells in the specific immune system. Dysfunction of dendritic cells provides an impairment of immune response to specific antigens. In anti-cancer host immunity, dendritic cells in tumor tissues and the regional lymph nodes act as antigen presenting cells against cancer. Decreases in dendritic cells in the tumor tissues and lymph nodes might weaken the host's anti-cancer immune responses. Our results suggest that cancer-derived HMGB1 inhibits dendritic cells and might suppress a wide range of the host's anti-cancer immune responses, which could contribute to metastasis to lymph nodes or distant organs. Further studies should examine effects of HMGB1 on distant metastasis of cancers.

In the present study, we examined monocytic dendritic cells but not plasmacytoid dendritic cells, which act as interdigitating cells in lymph nodes. HMGB1 is reported to be a maturation factor for plasmacytoid dendritic cells. HMGB1 showed different effects on macrophages: a low level of HMGB1 activates macrophages to secrete inflammatory cytokines $[10,14]$ and a high level of HMGB1 induces apoptosis of macrophages [21]. Therefore, a high level of HMGB1 might induce apoptosis of plasmacytoid dendritic cells.

In conclusion, HMGB1 shows obvious suppressive effects on the host's anti-cancer immunity and might be an important target for molecular therapy for colorectal cancer.

\section{Acknowledgement}

This work was supported in part by a grant-in-aid for scientific research from the Ministry of Health, Labour and Welfare, Japan. 


\section{References}

1 Wertel I, Barczynski B, Kotarski J: The role of dendritic cells in cytotoxic immune response regulation in ovarian cancer microenvironment. Front Biosci 2008;13:21772190.

$\checkmark 2$ Aloysius MM, Takhar A, Robins A, Eremin O: Dendritic cell biology, dysfunction and immunotherapy in gastrointestinal cancers. Surgeon 2006;4:195-210.

$\checkmark 3$ Schnurr M, Chen Q, Shin A, Chen W, Toy T, Jenderek $C$, et al: Tumor antigen processing and presentation depend critically on dendritic cell type and the mode of antigen delivery. Blood 2005;105:2465-2472.

4 Shunyakov L, Ryan CK, Sahasrabudhe DM, Khorana AA: The influence of host response on colorectal cancer prognosis. Clin Colorectal Cancer 2004;4:38-45.

5 Zeh HJ, Stavely-O'Carroll K, Choti MA: Vaccines for colorectal cancer. Trends Mol Med 2001;7:307-313.

-6 Naka T, Iwahashi M, Nakamura M, Ojima T, Nakamori M, Ueda K, et al: Tumor vaccine therapy against recrudescent tumor using dendritic cells simultaneously transfected with tumor RNA and granulocyte macrophage colony-stimulating factor RNA. Cancer Sci 2008;99:407-413.

$\checkmark 7$ Makala LH, Nishikawa Y, Kamada T, Xuan $\mathrm{X}$, Nagasawa $\mathrm{H}$ : Antigen presentation by murine peritoneal cavity macrophage-derived dendritic cells. Pathobiology 2001;69:104112.

$\checkmark 8$ Makala LH, Nishikawa Y, Mishima M, Inoue N, Xuan X, Suzuki H, et al: Phenotype and function of murine peritoneal cavity macrophage derived-dendritic cells. J Vet Med Sci 2002;64:813-820.

$\checkmark 9$ Sasahira T, Kirita T, Oue N, Bhawal UK, Yamamoto K, Fujii K, et al: High mobility group box-1-inducible melanoma inhibitory activity is associated with nodal metastasis and lymphangiogenesis in oral squamous cell carcinoma. Cancer Sci 2008;99:18061812 .

>10 Czura CJ, Wang H, Tracey KJ: Dual roles for HMGB1: DNA binding and cytokine. J Endotoxin Res 2001;7:315-321.
11 Huang JC, Zamble DB, Reardon JT, Lippard SJ, Sancar A: HMG-domain proteins specifically inhibit the repair of the major DNA adduct of the anticancer drug cisplatin by human excision nuclease. Proc Natl Acad Sci USA 1994;91:10394-10398.

12 Parkkinen J, Raulo E, Merenmies J, Nolo R Kajander EO, Baumann M, et al: Amphoterin, the $30-\mathrm{kDa}$ protein in a family of HMG1type polypeptides: enhanced expression in transformed cells, leading edge localization, and interactions with plasminogen activation. J Biol Chem 1993;268:19726-19738.

13 Huttunen HJ, Kuja-Panula J, Sorci G, Agneletti AL, Donato R, Rauvala H: Coregulation of neurite outgrowth and cell survival by amphoterin and S100 proteins through receptor for advanced glycation end products (RAGE) activation. J Biol Chem 2000;275: 40096-40105.

14 Wang $\mathrm{H}$, Bloom O, Zhang M, Vishnubhakat JM, Ombrellino M, Che J, et al: HMG-1 as a late mediator of endotoxin lethality in mice. Science 1999;285:248-251.

15 Kuniyasu H, Oue N, Wakikawa A, Shigeishi H, Matsutani N, Kuraoka K, et al: Expression of receptors for advanced glycation endproducts (RAGE) is closely associated with the invasive and metastatic activity of gastric cancer. J Pathol 2002;196:163-170.

16 Kuniyasu H, Chihara Y, Kondo H: Differential effects between amphoterin and advanced glycation end products on colon cancer cells. Int J Cancer 2003;104:722-727.

17 Kuniyasu H, Chihara Y, Takahashi T: Co-expression of receptor for advanced glycation end products and the ligand amphoterin associates closely with metastasis of colorectal cancer. Oncol Rep 2003;10:445-448.

18 Kuniyasu H, Chihara Y, Kondo H, Ohmori H, Ukai R: Amphoterin induction in prostatic stromal cells by androgen deprivation is associated with metastatic prostate cancer. Oncol Rep 2003;10:1863-1868.

19 Sasahira T, Kirita T, Bhawal UK, Ikeda M, Nagasawa A, Yamamoto K, et al: The expression of receptor for advanced glycation end products is associated with angiogenesis in human oral squamous cell carcinoma. Vir chows Arch 2007;450:287-295.
20 Sasahira T, Kirita T, Bhawal UK, Yamamoto $\mathrm{K}$, Ohmori H, Fujii K, et al: Receptor for advanced glycation end products (RAGE) is important in the prediction of recurrence in human oral squamous cell carcinoma. Histopathology 2007;51:166-172.

21 Kuniyasu H, Yano S, Sasaki T, Sasahira T, Sone S, Ohmori H: Colon cancer cell-derived high mobility group 1/amphoterin induces growth inhibition and apoptosis in macrophages. Am J Pathol 2005;166:751-760.

22 Kuniyasu H, Sasaki T, Sasahira T, Ohmori H, Takahashi T: Depletion of tumor-infiltrating macrophages is associated with amphoterin expression in colon cancer. Pathobiology 2004;71:129-136.

23 Scaffidi P, Misteli T, Bianchi ME: Release of chromatin protein HMGB1 by necrotic cells triggers inflammation. Nature 2002;418: 191-195.

24 Gallucci S, Lolkema M, Matzinger P: Natural adjuvants: endogenous activators of dendritic cells. Nat Med 1999;5:1249-1255.

$>25$ Lotze MT, Tracey KJ: High-mobility group box 1 protein (HMGB1): nuclear weapon in the immune arsenal. Nat Rev Immunol 2005; 5:331-342.

26 Blanco P, Palucka AK, Pascual V, Banchereaud J: Dendritic cells and cytokines in human inflammatory and autoimmune diseases. Cytokine Growth Factor Rev 2008;19: 41-52.

27 Kuniyasu H, Yasui W, Kitahara K, Naka K, Yokozaki H, Akama Y, et al: Growth inhibitory effect of interferon-beta is associated with the induction of cyclin-dependent kinase inhibitor p27Kip1 in a human gastric carcinoma cell line. Cell Growth Differ 1997; 8:47-52.

28 Kuniyasu H, Yasui W, Pettaway CA, Yano S, Oue N, Tahara E, et al: Interferon-alpha prevents selection of doxorubicin-resistant undifferentiated-androgen-insensitive metastatic human prostate cancer cells. Prostate 2001;49:19-29.

29 Sasahira T, Sasaki T, Kuniyasu H: Interleukin-15 and transforming growth factor a are associated with depletion of tumor-associated macrophages in colon cancer. J Exp Clin Cancer Res 2005;24:69-74 